\title{
Determination of Optimal Glucose Concentration for Microcalorimetric Metabolic Evaluation of Equine Spermatozoa
}

\author{
André Belico de Vasconcelos ${ }^{1 *}$, Patrícia Castanheira de Souza ${ }^{1}$, Fabiana Cristina Varago ${ }^{1}$, \\ Monique de Albuquerque Lagares ${ }^{1}$ and Marcelo Matos Santoro ${ }^{2}$ \\ ${ }^{I}$ Departamento de Clínica e Cirurgia Veterinária; Escola de Veterinária; Universidade Federal de Minas Gerais; \\ Belo Horizonte - MG - Brasil. ${ }^{2}$ Departamento de Bioquímica e Imunologia; Instituto de Ciências Biológicas; \\ Universidade Federal de Minas Gerais; Belo Horizonte - MG - Brasil
}

\begin{abstract}
The heat conduction microcalorimeter can be used to evaluate the metabolic rates of the sperm cell. Two ejaculates of four stallions were cooled to $+5^{\circ} \mathrm{C}$ and checked for sperm motility (bright field microscopy), viability (eosin 3\%), functional membrane integrity (hyposmotic swelling test), and heat production (microcalorimetry). Glucose and sperm cell concentrations were determined in order to measure the heat outputs resulting from sperm metabolism. Sperm viability, membrane integrity and sperm motility did not differ among the different glucose concentrations tested. Nevertheless, the highest heat output detected by the microcalorimeter was obtained with 6 mM glucose and $10^{8}$ spermatozoa/mL. Since conduction microcalorimetry offered additional information on equine sperm metabolism, it could be used as a method to study equine semen preservation.
\end{abstract}

Key words: Microcalorimetry, Glucose, Spermatozoa, Sperm metabolism, Cell viability, Equine

\section{INTRODUCTION}

Studies on sperm cells have been undertaken to increase the success in "in vitro" and "in vivo" reproduction. Further studies on semen preservation are necessary, due to lower fertility rates with cryopreserved equine semen as compared to fresh semen. Fertilization suitability of spermatozoa has been evaluated "in vitro" in routine practices by parameters such as sperm motility and morphology (Pickett and Back, 1973; Mckinnon and Voss, 1992). Although sperm motility evaluated by microscopy offers information on spermatozoa metabolic activity, it does not detect damage on the sperm membrane or sperm metabolism caused by a decrease in temperature, necessary for cryopreservation (Pickett and Back, 1973; Jasko et al., 1990; Mckinnon and Voss, 1992).

Spermatozoa rely primarily on extracellular substrates to meet their energy requirements. This energy is mainly derived from carbohydrates (Mann, 1975). Spermatozoa readily metabolize monosaccharides such as glucose and fructose but do not metabolize all sugars or more complex carbohydrates (Hammerstedt, 1975). Stallion spermatozoa, however, possess limited capacity to use fructose when compared with spermatozoa

\footnotetext{
* Author for correspondence: andre_belico@yahoo.com.br
} 
from other species and use other exogenous substrates including lactic acid, glycerol, fatty acids and amino acids (Yanagimachi, 1974). Nevertheless, equine spermatozoa cannot metabolize sorbitol, the major component of stallion seminal plasma. On the other hand, ram spermatozoa in neat semen metabolize all the available monosaccharides in seminal plasma within 15 to $20 \mathrm{~min}$ at $37^{\circ} \mathrm{C}$ and, then, they stop swimming. However, this does not occur with stallion spermatozoa (Squires et al., 1988).

Cells obtain supplies of Gibbs free energy in the form of carbon substrate from their environment in order to stay alive. The cell mitochondria appears to be the major site where most of the useful energy is captured in the form of high-energy intermediate ATP (Mann and Lutwak-Mann, 1981; Fontana et al., 1990; Gnaiger and Kemp, 1990). In the overall processes involving oxidation of metabolic fuel, production of ATP and macromolecule synthesis, a proportion of energy is returned to the environment in the form of heat (Mann and Lutwak-Mann, 1981).

ATP synthesis is a central process in metabolic heat production. The amount of heat released by a specific metabolic reaction can be precisely related to the stoichiometry of the reaction (Hammerstedt, 1975; Inskeep and Hammerstedt, 1985). Therefore, the stoichiometry for ATP yield per mole of substrate transformed permits calculation of the rate of ATP synthesis for any given pathway. Each rate of substrate consumption, expressed in glucose equivalents, is multiplied by values for heat released $(\mathrm{mJ} / \mu \mathrm{mol}$ glucose) to yield the heat production rates (Mann and LutwakMann, 1981; Inskeep and Hammerstedt, 1985). The sperm cell provides an ideal model system of biosynthesis, since it has no pathways of intermediate metabolism (Mann, 1975; Mckinnon and Voss, 1992).

Nevertheless, there are different conditions for the metabolism pathways among spermatozoa of various species. Boar and guinea pig spermatozoa can maintain motility only in the presence of $\mathrm{O}_{2}$, whilst human and bovine spermatozoa maintain their motility under aerobic and anaerobic conditions (Krzyzoiak et al., 1999).

Thus, the metabolic efficiency of a system could be assessed from the ratio of oxygen consumed to the heat produced, in which the more efficient system displays the higher ratio (Gnaiger and Kemp, 1990; Bäckman et al., 1992).
Microcalorimetry has been an important tool for the study of metabolic activities of cells and biological tissues (Bäckman et al., 1992; Kemp and Guan, 2000; Kemp , 2001; Lee and Kaletunc, 2002). Isothermal heat rates have been measured for the intact cells by both batch and flow calorimetry and relate to such properties as growth rates, thermodynamic parameters and effects of activators (Kemp, 1991; Krzyzoiak et al., 1999; Wadsö et al., 2001). As an alternative, the characterization of cellular metabolism microcalorimetry has been studied by the determination of the total sum of metabolic events in a cell population. Since conduction microcalorimetry quantifies the energy produced by spermatozoa, the aim of this work was to test its usefulness in evaluating sperm cell metabolism of equine semen cooled under conditions in which the level of initial $\mathrm{O}_{2}$ concentration in the diluent was constant.

\section{MATERIALS AND METHODS}

\section{Calorimetry}

The conduction microcalorimeter (Mares-Guia et al., 1990; Kemp 1991) consisted of two glass vessels, each one serving as a reference for the other. The vessels were $35 \mathrm{~mm}$ in diameter and 5 to $7 \mathrm{~mm}$ in thickness. The two vessels were located between two Seebeck thermopiles. The reference vessel was connected opposite to the sample vessel. Each vessel had two chambers ( $5 \mathrm{~mL}$ total). The smaller chamber held $0.5-1.0$ $\mathrm{mL}$, while the larger chamber could receive $1.0-$ $2.0 \mathrm{~mL}$.

The instrument had a calorimetric constant close to $7 \mu \mathrm{W} / \mu$ volt output signal. The production of total heat was calculated starting from the integrated area of the curve. Amplifiers transformed signals of $1 \mu$ Volt into $7 \mu \mathrm{W}$. The calorimeter was housed in a constant temperature box under isothermal conditions under a temperature of $30 \pm 1^{\circ} \mathrm{C}$ (Irving andWadsö, 1964; Inskeep and Hammerstedt, 1983). Calibration was performed by neutralization of Tris (hydroxymethyl) aminomethane by $\mathrm{HCl}$ based with a heat of (-) $47234 \mathrm{~J} /$ mole of neutralized $\mathrm{H}^{+}$(Kemp, 1991).

\section{Semen Evaluation}

Two ejaculates of four stallions were collected $(n=8)$, by means of a "Hannover" artificial vagina. 
Semen samples were evaluated for appearance, volume, sperm cell number with a haemocytometer chamber, and for progressive motility by bright field microscopy (100x). Only ejaculates containing a minimum of $50 \%$ of spermatozoa with progressive motility were used.

Then, the semen was then diluted with Kenney extender (Kenney et al., 1975) in order to obtain samples containing a sperm cell number of approximately $10^{9}$ spermatozoa $/ \mathrm{mL}$. Semen samples were cooled to $5^{0} \mathrm{C}$ within two hours, according to the following procedure: from 35 to $20^{\circ} \mathrm{C}\left(1^{\circ} \mathrm{C} / \mathrm{min}\right)$, and from 20 to $5^{\circ} \mathrm{C}\left(0.08^{0} \mathrm{C} / \mathrm{min}\right)$. After cooling, the semen samples were analysed by microcalorimetry within two to four hours.

The heat production of equine spermatozoa loaded in the conduction microcalorimeter was assessed in semen samples of one $\mathrm{mL}$. Before and after the microcalorimetric assays, sperm motility, viability, and membrane integrity were evaluated. The control group consisted of semen samples evaluated before the microcalorimeter assays. Eosin staining (3\%) was used to evaluate equine sperm viability. A total number of 200 spermatozoa were evaluated by brightfield microscopy (400x), in which unstained sperm cell was considered viable (Blom, 1950). The hyposmotic swelling test (HOST) (Lagares et al., 2000) was used to analyze the membrane functional integrity of equine spermatozoa. Semen samples were diluted in the proportion of $1: 3$ with distilled water during five minutes at $37^{\circ} \mathrm{C}$ and 200 spermatozoa were evaluated by bright field microscopy (400x) for sperm tail swelling.

Sperm number and glucose concentration determination for the calorimetric assay

In order to determine the highest heat output produced by equine sperm cells detected by microcalorimetry, different numbers of spermatozoa $\left(1 \times 10^{7} ; 5 \times 10^{7} ; 1 \times 10^{8} ; 5 \times 10^{8} ; 1 \times 10^{9}\right.$ spermatozoa $/ \mathrm{mL}$ ) were studied. Since glucose is considered as the carbohydrate of choice to induce equine sperm motility, the heat outputs produced by equine sperm cells, in different glucose concentrations $(3,6$ and $12 \mathrm{mM})$, were tested. The number of sperm cell $/ \mathrm{mL}$ was determined by haemocytometry.

One milliliter of diluted semen sample with the same number of spermatozoa was added to the larger reference (R) chambers and sample (S) vessels. The smaller reference chamber received $0.5 \mathrm{~mL}$ of PBS buffer, whereas in the $\mathrm{S}$ vessel, the smaller chamber received $0.5 \mathrm{~mL}$ of solution of different glucose concentrations diluted in PBS.

In order to determine the optimal sperm number to be put in the cell, the same glucose concentration $(6 \mathrm{mM})$ in $0.5 \mathrm{~mL}$ of PBS buffer was added to the smaller chambers of $\mathrm{R}$ and $\mathrm{S}$ vessels. The larger reference chamber received one $\mathrm{mL}$ of Kenney extender, whereas in the $\mathrm{S}$ vessel, the larger chamber received different amounts of sperm diluted in $1.0 \mathrm{~mL}$ of the extender.

Glucose and semen samples were mixed with the aid of a system consisting of a handle attached to the inner side of the calorimeter.

\section{Lactate estimation}

The measurement of the lactate concentration was carried out after the calorimetric experiments using the 2300 STAT PLUS Glucose and LLactate Analyzer (YSI Incorporated, Yellow Springs Ohio)

\section{Statistical analysis}

The regression curves for the cooled semen and calibration of the calorimeter were calculated with the software (Origin version 5). The same program was used to analyze and prepare the graphs shown in Results and Discussion.

The nonparametric analysis of the Friedmann test was used to evaluate the percentage of progressive motile spermatozoa. The parameters of viable and intact plasma membrane of spermatozoa were analysed by ANOVA.

\section{RESULTS AND DISCUSSION}

\section{Calorimeter Calibration}

To determine the reproducibility of the calorimetric experiment, four calibrations using different concentrations of $\mathrm{HCl}(0.5 \mathrm{mM} ; 1.0 \mathrm{mM}$; $2.0 \mathrm{mM} ; 4.0 \mathrm{mM}$ ) were performed (Irving and Wadsö, 1964). The heat released, between 2 and $25 \mathrm{~mJ}$, corresponded to the neutralization energy between $0.2 \mu \mathrm{mol}$ and $2.5 \mu \mathrm{mol}$ of $\mathrm{H}^{+}$, respectively. The resulting calibration curve is shown in Fig. 1. The energy produced by the calibration process demonstrated that the calibration data obtained were similar to the calculated data as shown in Fig 1. Therefore, the calibration data obtained did not need any correction. Standard calibration plots were described as follows: $A=1.028 x q+0.0266$, in which $\mathrm{A}$ is the integrated area under the output 
envelope, and $\mathrm{q}$ is the amount of heat released. These results were also reported by Mares-Guia et al., 1990 and Irving and Wadsö , 1964, in which calibration was also performed by neutralization of Tris by $\mathrm{HCl}$, based on heat of (-) $47234 \mathrm{~J} / \mathrm{mole}$ of neutralized $\mathrm{H}^{+}$.

\section{Sperm cell concentration effect}

The highest heat output detected by the conduction microcalorimeter was obtained with $10^{8}$ spermatozoa/mL (Table 1).

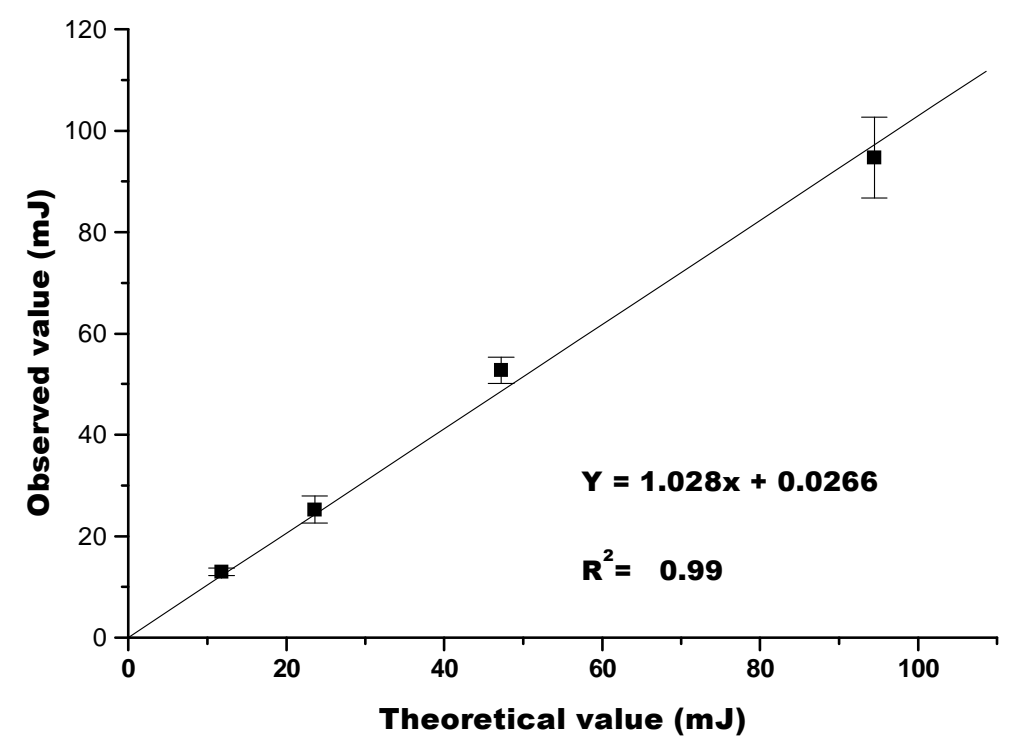

Figure 1 - Microcalorimeter calibration curve based on heat produced at $30^{\circ} \mathrm{C}$ by neutralization of the base Tris (hydroxymethyl) aminomethane by hydrochloric acid ( $\mathrm{HCl})$.

Table 1 - Heat output detected by the conduction microcalorimeter and lactate determination as a function of sperm cell concentration

\begin{tabular}{lccccc}
\hline Spermatozoa $/ \mathrm{mL}$ & $1 \times 10^{7}$ & $5 \times 10^{7}$ & $1 \times 10^{8}$ & $5 \times 10^{8}$ & $1 \times 10^{9}$ \\
Lactate $(\mathrm{nmol} / \mathrm{L})$ & $0.87^{\mathrm{c}}$ & $1.10^{\mathrm{b}}$ & $1.14^{\mathrm{b}}$ & $1.16^{\mathrm{b}}$ & $1.26^{\mathrm{a}}$ \\
Heat output $(\mathrm{mJ})$ & $150^{\mathrm{d}} \pm 43.1$ & $2360^{\mathrm{b}} \pm 76.3$ & $3011^{\mathrm{a}} \pm 185.9$ & $2018^{\mathrm{b}} \pm 78.6$ & $256^{\mathrm{c}} \pm 32.9$ \\
\hline
\end{tabular}

Data with different superscript letters within the same line were statistically different $(\mathrm{p}<0.05)$. Glucose concentration= $6 \mathrm{Mm}$. $($ mean $\pm \mathrm{SD})$. One replicate of two ejaculates ( $\mathrm{n}=4$ stallions).

Similar results were also reported for bovine spermatozoa (Inskeep and Hammersted, 1983).

While the lowest number of spermatozoa/mL $\left(10^{7}\right)$ barely produced enough heat to be detected by the calorimeter, the highest spermatozoa concentration tested $\left(10^{9}\right)$ did not produce the higher heat output as expected. This effect was probably due to the large number of spermatozoa in small volumes, which was denominated "crowding effect". Thus, cell decantation and oxygen depletion occurred as reported in Leishmania (Mares-Guia et al., 1990), human leukaemia cells (Nittinger et al., 1990), and animal cells (Kemp 1991; Kemp, 2001). In order to evaluate the "crowding effect" at $10^{9}$ spermatozoa $/ \mathrm{mL}$, the semen samples were diluted with Kenney extender to $10^{8}$ spermatozoa $/ \mathrm{mL}$. The heat outputs from these semen samples, before and after ten-fold dilution, were $256 \pm 32.9 \mathrm{~mJ}$ and $3116 \pm 174 \mathrm{~mJ}$, respectively. When the sample with an animal sperm number of $10^{8}$ spermatozoa $/ \mathrm{mL}$ was tested, as shown in Table 1, a similar result was observed $(3011 \pm 185.9 \mathrm{~mJ})$. Thus, it could be concluded that $10^{8}$ spermatozoa/mL was the ideal sperm number to be used under these conditions. 


\section{Glucose concentration}

As observed in Fig 2, metabolic rate changes were induced by different glucose concentrations. At a concentration of $10^{8}$ spermatozoa $/ \mathrm{mL}$, addition of $3 \mathrm{mM}$ glucose produced the lowest values of heat output $(+113.9 \pm 15.0 \mathrm{~mJ})$ detected by the microcalorimeter, whereas the addition of the highest glucose concentration $(12 \mathrm{mM})$ did not result in the highest energy values $(+748.1 \pm 93.5 \mathrm{~mJ})$.

The heat released by the spermatozoa with the addition of $3 \mathrm{mM}$ glucose was similar to that obtained for the sperm endogenous metabolism $(+109.6 \pm 12.0 \quad \mathrm{~mJ}) \quad($ Table 2$) . \quad$ Endogenous metabolism of the spermatic cell was due to the oxidation of phospholipids in the mitochondria (Yanagimachi, 1974; Mann, 1975; Hammerstedt et al., 1988).

Inskeep and Hammerstedt (1985) estimated that $10 \%$ of the heat produced by sperm with a functional electron transport system was the result of endogenous substrate mobilization.

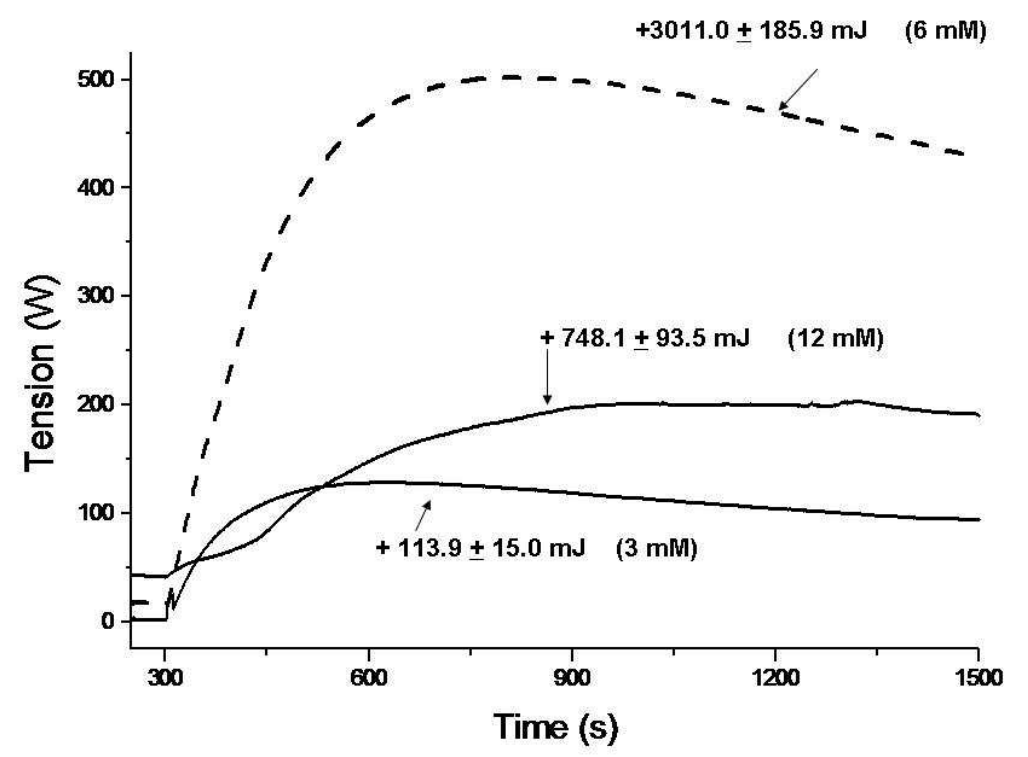

Figure 2 - Heat production of $10^{8}$ sperm cells in response to different glucose concentrations. The values $(\mathrm{mJ})$ were obtained by numerical integration of the areas under the curves, between 300 s and 1500s. (mean \pm SD). One replicate of two ejaculates ( $n=4$ stallions).

Table 2 - Percentage of sperm viability, intact membrane sperm, progressive motile, lactate concentration, and heat production of spermatozoa in different glucose concentrations.

\begin{tabular}{cccccc}
\hline $\begin{array}{c}\text { Glucose } \\
\text { concentration } \\
(\mathbf{m M})\end{array}$ & $\begin{array}{c}\text { Viable sperm } \\
(\boldsymbol{\%})\end{array}$ & $\begin{array}{c}\text { Intact } \\
\text { membrane } \\
(\boldsymbol{\%})\end{array}$ & $\begin{array}{c}\text { Progressive } \\
\text { motile } \\
(\boldsymbol{\%})\end{array}$ & $\begin{array}{c}\text { Lactate } \\
(\mathbf{n m o l} / \mathbf{L})\end{array}$ & $\begin{array}{c}\text { Heat Output } \\
(\mathbf{m J})\end{array}$ \\
\hline 0 & $75 \pm 5^{\mathrm{a}}$ & $32 \pm 5^{\mathrm{a}}$ & $34 \pm 5^{\mathrm{b}}$ & $0.89^{\mathrm{b}}$ & $109.6^{\mathrm{c}} \pm 12.0$ \\
3 & $77 \pm 5^{\mathrm{a}}$ & $34 \pm 7^{\mathrm{a}}$ & $48 \pm 6^{\mathrm{a}}$ & $0.96^{\mathrm{b}}$ & $113.9^{\mathrm{c}} \pm 15.0$ \\
6 & $81 \pm 6^{\mathrm{a}}$ & $37 \pm 6^{\mathrm{a}}$ & $56 \pm 6^{\mathrm{a}}$ & $1.14^{\mathrm{a}}$ & $3011.0^{\mathrm{a}} \pm 185.9$ \\
12 & $78 \pm 6^{\mathrm{a}}$ & $32 \pm 6^{\mathrm{a}}$ & $51 \pm 5^{\mathrm{a}}$ & $1.19^{\mathrm{a}}$ & $748.1^{\mathrm{b}} \pm 93.5$ \\
\hline
\end{tabular}

An amount of $10^{8}$ spermatozoa/mL was used in each experiment. Data with different superscript letters within the same column were statistically different $(\mathrm{p}<0.05)$ (mean $\pm \mathrm{SD})$. One replicate of two ejaculates $(\mathrm{n}=4$ stallions). 
On the other hand, at a high glucose concentration, an inhibitory effect on sperm metabolism was observed. The heat flow is directly linked to cellular metabolism and this is related to the number of viable cells (Kemp, 2001). Lardy and Philips (1941), cited by Mújica et al., (1991), showed that glucose decreased oxygen consumption in bull spermatozoa, named as the "glucose effect" and that glucose shifted the sperm metabolism to the glycolytic pathway (Table 2). This effect was also reported for Leishmania (Mares-Guia et al., 1990) and mammalian cells (Wadsö, 1988). It induces the anaerobic metabolism by spermatozoa due to a low oxygen concentration (Gnaiger and Kemp, 1990; Krzyzoiak et al., 1999). Thus, the low energy production observed could reflect the change in the metabolic route from aerobic to anaerobic, when the cells were in the presence of a large substrate concentration (Fig 2). This explained the relationship between the amount of lactate and heat output (Table2), as a large amount of lactate might lower the solvent $\mathrm{pH}$, as suggested by Kemp (2001), although it did not affect cell viability.

The largest amount of heat released by the spermatozoa in the presence of $6 \mathrm{mM}$ of glucose $(+3011.0+185.9 \mathrm{~mJ})$ (Fig 2). Similar calorimetric results were also obtained adding $6 \mathrm{mM}$ of glucose to bovine sperm cells (Inskeep and Hammerstedt, 1983; Hammerstedt and Lovrien, 1983). This strongly implied a ready-to-go cell machinery to use glucose. Since the amount of heat released by a specific metabolic reaction could be precisely related to the stoichiometry of the reaction (Inskeep and Hammerstedt, 1985; Hammerstedt et al., 1988), this substrate concentration was ideal to keep the main functions of the sperm cells (Mann, 1975; Hammerstedt, 1975; Iskeep and Hammerstedt 1985). The destination of the exogenous substrate in the metabolic pathways was reported in a work described by Nittinger et al. (1990) with bull sperm, which determined the heat production for different operational metabolic pathways.

The percentage of viable and intact plasma membrane spermatozoa did not differ in the various glucose concentrations ( $p>0.05$ ). Thus, it was possible that the control of hexose-transporter across the plasma membrane did not improve the sperm membrane integrity and viability in the presence of glucose (Angulo et al., 1998). Therefore, a minimum of substrate concentration was necessary for the cellular metabolism maintenance (Table 2).

Sperm motility subjectively evaluated by the microscopy did not differ at the three different glucose concentrations. Nevertheless, it was higher compared to the control sample (Table 2). The highest heat production detected by the microcalorimeter could be observed by adding $6 \mathrm{mM}$ of glucose, after $30 \mathrm{~min}$. However, this energy increase could not be detected by the sperm motility analysis. It could be possible that after 30 minutes, glucose was metabolized and, therefore, no sperm motility difference among the semen samples was observed. The time required by the equine spermatozoa to return to the baseline heat values established during the calorimetric run (before the contact of the semen samples with glucose) was 45, 45, 80 and $60 \mathrm{~min}$ for control; 3, 6 and $12 \mathrm{mM}$ of glucose addition, respectively. At $6 \mathrm{mM}$ glucose, equine spermatozoa showed the highest energy values as well as the greatest sperm longevity $(80 \mathrm{~min})$. Therefore, $6 \mathrm{mM}$ could be considered the best glucose concentration to be used in microcalorimetric studies of stallion spermatozoa metabolism.

Since the conduction microcalorimeter offered additional information on equine sperm metabolism, it could also be used as a method to study the spermatozoa metabolic pathways for different periods of time and submitted to different substances and conditions.

\section{ACKNOWLEDGEMENTS}

The $C N P q$ and the Universidade Federal de Minas Gerais supported this work.

\section{RESUMO}

O microcalorímetro de condução pode ser usado para avaliar as taxas metabólicas do espermatozóide equiino. Dois ejaculados de quatro garanhões foram avaliados quanto à motilidade progressiva pela microscopia, viabilidade espermática (eosina 3\%), integridade funcional da membrana (teste hiposmótico) e produção de calor (microcalorimetria). Concentrações ótimas de glicose e de células espermáticas foram determinadas, para mensurar o calor liberado resultante do metabolismo espermático em relação 
à capacidade de detecção do calor pelo microcalorímetro. Não foi observada diferença da motilidade, viabilidade e integridade funcional de membrana espermática quando adicionada glicose nas três concentrações estudadas. No entanto a avaliação por microcalorimetria ressaltou um maior fluxo de calor a uma concentração de $6 \mathrm{mM}$ de glicose e uma concentração espermática de $10^{8}$ espermatozóides $/ \mathrm{mL}$. Portanto, a técnica de microcalorimetria oferece informações adicionais sobre o metabolismo tornando-se uma ferramenta importante no estudo do processo de preservação do sêmen eqüino.

\section{REFERENCES}

Angulo,C., Rauch,M.C., Droppelmann,A., Reyes,M., Slebe,J.C., Delgado-Lopez,F., Guaiquil,V.H., Vera,J.C. and Concha,I.I. (1998), Hexose transporter expression and function in mammalian spermatozoa: cellular localization and transport of hexoses and vitamin C. J. Cell. Biochem., 71, 189-203.

Bäckman, P., Kimuta,T., Schön, A. and Wadsö, I. (1992), Effects of pH-variations on the kinetics of growth and energy metabolism in culture $\mathrm{T}$ lymphoma cells: A microcalorimetric study. J.Cell. Physiol.,150, 99-103.

Blom, E. (1950), A one-minute live-dead sperm stain by means of eosin-nigrosin. Fertil. Steril.,1, 176-177.

Fontana,A.J., Hansen,L.D., Breidenbach,R.W. and Criddle,R.S. (1990), Microcalorimetric measurement of aerobic cell metabolism in unstirred cell cultures. Thermochim. Acta., 172, 105-113.

Gnaiger, E. and Kemp, R.B. (1990), Anaerobic metabolism in aerobic mammalian cells: information from the ratio of calorimetric heat flux and respirometrc oxygen flux. Biochim. Biophys. Acta., 10, 328-332.

Hammerstedt, R.H. (1975), Tritium release from [2- $\left.{ }^{3} \mathrm{H}\right]$ D-glucose as a monitor of glucose consumption by bovine sperm. Biol. Reprod., 12, 545-551.

Hammerstedt, R.H. and Lovrien, R.E. (1983), Calorimetric techniques for metabolic studies of cells and organisms under normal conditions and stress. $J$. Exp. Zool., 22, 459-469.

Hammerstedt,R.H., Volonte,C., Racker, E. (1988), Motility, Heat, and Lactate Production in Ejaculated Bovine Sperm, Archives do Biochemistry and Biophysics.,226,1111-123.

Inskeep, P.B. and Hammerstedt, R.H. (1983), A colorimetric method to assess endogenous metabolism and its application to the study of bovine sperm. J.Biochem. Biophys. Methods., 7, 199-210.

Inskeep, P.B. and Hammerstedt, R.H. (1985), Endogenous metabolism by sperm in response to altered cellular ATP requirements. J.Cell.Physiol., 123,180-190.

Irving, R.J. and Wadsö, I. (1964), Use of Tris (Hydroxymethyl) aminomethane as a test substance in reaction calorimetry. Acta. Chem. Scand., 18,195201.

Jasko,D.L., Lein,D.H., Foote,R.H. (1990), A comparison of two computer-automated semen analysis instruments for the evaluation of sperm motion characteristics in the stallion. J.Androl., 11, 453-459.

Kemp, R.B. (1991), Calorimetric studies of heat flux in animal cells. Thermochim. Acta., 10, 253-267.

Kemp R.B., Guan Y.H. (2000), The application of heat flux measurements to improve the growth of mammalian cells in culture. Thermochim. Acta., 349, 23-30.

Kemp R.B. (2001), The application of heat conduction microcalorimetry to study the metabolism and pharmaceutical modulation of cultured mammalian cells. Thermochim. Acta., 380, 229-244.

Kenney,R.M., Bergmann,R.V., Cooper,W.L. and Morse, G.W. (1975), Minimal contamination technique for breeding mares: technique and preliminary findings. Proc. Am. Assoc. Equine. Pract., 21, 327-336.

Krzyzoiak,J.,Molan,P.,Vishwanath,R.

(1999), Measurements of bovine sperm velocities under true anaerobic and aerobic conditions. Animal Reproduction Science., 55, 163-173.

Lagares, M.A., Petzoldt, R., Sieme, H. and Klug,E. (2000), Assessing equine sperm-membrane integrity Andrologia., 32, 163-167.

Lee, J., Kaletunc, G. (2002), Calorimetric determination of inactivation parameters of micro-organisms. Journal of Applied Microbiology., 93, 178-189.

Mann, T. (1975), Biochemistry of stallion semen. $J$. Reprod. Fertil., 23,47-52.

Mann, T., and Lutwak-Mann, C. (1981), Examination of spermatozoa and isolated structural components. In: Mann, T. and Lutwak-Mann, C. (Eds) Male reproductive function and semen. Berlin Heidelberg. New York. pp . 63-69.

Mares-Guia, M., Nascimento, V.V., Lovrien, R. and Melo, M.N. (1990), Microcalorimetric determination of glucose utilization by Leishmania. Thermochim. Acta.,172, 203-211.

Mckinnon, A.O., Voss, J. L. (1992), Equine Reproduction. (Eds) Libray of congress Cataloging ., pp.705- 745 .

Mújica,A., Moreno-Rodriguez,J., Nacif,L., Neri,L., Tash,J.S.(1991), Glucose regulation of guinea-pig sperm motility. J. Reprod. Fertil.,92, 75-87.

Nittinger, J.,Tejmar-Kolar,L.,Furst,P. (1990), Microcalorimetric investigations on human leukemia cells - Molt 4. Biol Cell., 70, 139-142.

Pickett, B.W., Back, D.G. (1973), Procedures for preparation, collection, evaluation and insemination 
of stallion semen. Animal Reproduction Laboratory General Series Bulletin., 935, 1973.

Squires, E.L., Amann, R.P., Mckinnon, A.O. and Pickett, B.W. (1988), Fertility of equine spermatozoa cooled to +5 or $+20^{\circ} \mathrm{C}$. In: International Congress on Animal Reproduction and Artificial Insemination. Proc. Haia., 3, 297-299.

Yanagimachi, R. (1974), Mammalian Fertilization. In: Knobil, E and Neil, J.D. (Eds) The Physiology of Reproduction. Raven Press, Ltd., New York. pp.189281.
Wadsö, L., Smith, A.L., Shirazi, H., Mulligan, S. R., Hofelich, T. (2001), The Isothermal Heat Conduction Calorimeter: A Versatile Instrument for Studying Processes in Physics, Chemistry, and Biology. Journal of Chemical Education., 78, 1080-1086.

Wadsö, I. (1988), Progress and problems in microcalorimetric work am mammalian cell systems. Thermochim Acta.,137,1-10
Received: March 22, 2007; Revised: August 27, 2007; Accepted: February 05, 2009. 